\title{
Novel Approach to Evaluate Central Autonomic Regulation in Attention Deficit/Hyperactivity Disorder (ADHD)
}

\section{N. SEKANINOVA ${ }^{1,2}$, M. MESTANIK ${ }^{2,1}$, A. MESTANIKOVA ${ }^{1,2}$, A. HAMRAKOVA $^{1,3}$, I. TONHAJZEROVA ${ }^{1,2}$}

${ }^{1}$ Department of Physiology, Jessenius Faculty of Medicine in Martin, Comenius University in Bratislava, Martin, Slovak Republic, ${ }^{2}$ Biomedical Center Martin, Jessenius Faculty of Medicine in Martin, Comenius University in Bratislava, Martin, Slovak Republic, ${ }^{3}$ Psychiatric Clinic, Jessenius Faculty of Medicine in Martin, Comenius University in Bratislava, University Hospital Martin, Martin, Slovak Republic

Received March 7, 2019

Accepted April 15, 2019

Epub Ahead of Print June 6, 2019

\section{Summary}

Attention deficit/hyperactivity disorder (ADHD) is one of the most commonly diagnosed developmental disorders in childhood characterized by hyperactivity, impulsivity and inattention. ADHD manifests in the child's development by deficits in cognitive, executive and perceptor-motor functions, emotional regulation and social adaptation. Although the exact cause has not yet been known, the crucial role in the development of this disease plays the interaction of genetic, neurobiological and epigenetic factors. According to current knowledge, ADHD is defined as a biological dysfunction of central nervous system with genetically or organically defined deficits in noradrenergic and dopaminergic neurotransmission associated with structural abnormalities, especially in prefronto-striatal regions. In this context, a significant part of the difficulties could be due to a faulty control of fronto-striato-thalamo-cortical circuits important for attention, arousal and executive functions. Moreover, ADHD is associated with abnormal autonomic regulation. Specifically, reduced cardiac-linked parasympathetic activity associated with relative sympathetic dominance indexed by low heart rate variability can represent a noninvasive marker for prefrontal hypoactivity. However, the mechanisms underlying altered autonomic regulation in ADHD are still unknown. In this aspect, the evaluation of central autonomic regulation by noninvasive methods, namely pupillometry and eye-tracking, may provide novel information for better understanding of the neurobiological pathomechanisms leading to ADHD.

\section{Key words}

ADHD • Neurobiology • Autonomic regulation • Pupillometry • Eye-tracking

\section{Corresponding author}

I. Tonhajzerova, Department of Physiology and Biomedical Center Martin, Jessenius Faculty of Medicine in Martin, Comenius University in Bratislava, Mala Hora 4C, 03601 Martin, Slovak Republic. E-mail: tonhajzerova@jfmed.uniba.sk

\section{Introduction}

ADHD (Attention Deficit Hyperactivity Disorder according to American classification DSM-V) is a mental disease in the childhood with the highest prevalence, approximately $8-12 \%$ worldwide, with a more frequent occurrence among boys compared to girls in a ratio of 3-5:1 (Biederman and Faraone 2005, Skogli et al. 2013). ADHD is a common neurodevelopmental disorder characterized by pervasive and developmentally inappropriate levels of impulsivity, hyperactivity and inattention lasting at least 6 months with the beginning before the seventh year of age of the child and wide-ranging cognitive and behavioral impairments, including deficits in working memory, inhibitory control, and altered motivation (Sonuga-Barke 2002). According to current knowledge, ADHD is 
defined as a biological dysfunction of central nervous system (CNS) with genetically or organically defined deficits in noradrenergic and dopaminergic neurotransmission. It is suggested that part of the difficulties of ADHD is due to a faulty control of frontostriato-talamo-cortical circuits important for the management of behavioral responses such as attention, arousal and executive functions (Barkley 1997). Moreover, according to Neurovisceral and Polyvagal theory (Porges 1995, Thayer and Lane 2000, Porges 2007) these brain regions are part of a complex autonomic network described by Benarroch (1993) modulating the output to the sympathetic and parasympathetic neurons. Thus, the abnormalities in autonomic regulatory mechanisms could reflect pathomechanisms linked to ADHD.

This article is aimed to summarize the latest findings in the neurobiology of ADHD with focus on pupillometry and eye-tracking as novel methods suitable for quantifying of central autonomic regulation/dysregulation associated with ADHD.

\section{Neurobiology of ADHD}

In the neurobiology of ADHD, several major research areas, namely neuroimaging, neurophysiology and neurochemistry, and genetics show that specific brain abnormalities are involved in the ADHD pathophysiology leading to changes in biochemical regulation in the brain (Doggett 2004).

\section{Neuroimaging studies}

Relationships between brain morphology and ADHD can be identified by various neuroimaging methods, mainly magnetic resonance imaging (MRI) and its modalities. In MRI, the T1 imaging weighting is used for the assessment of brain macrostructure, such as volume and structure of white and gray matter, and the diffusion tensor imaging (DTI) for the assessment of brain microstructure, specifically to assess the integrity of the white matter pathways (Song et al. 2005). Initial brain macrostructural studies revealed that children suffering from ADHD show smaller brain volumes in all regions (Castellanos et al. 2002) however, some meta-analyses report differences mainly in basal ganglia with total brain or grey matter volume (Valera et al. 2007, Ellison-Wright et al. 2008, Nakao et al. 2011). Specifically, ADHD patients are characterized by reductions in total cerebral volume, prefrontal cortex, basal ganglia (striatum), dorsal anterior cingulate cortex, splenium of the corpus callosum, and cerebellum, in particular the posterior inferior vermis (Emond et al. 2009). These widespread macrostructural changes suggest that many areas of the brain are associated with ADHD diagnosis in childhood. In children and adolescents, ADHD symptoms such as distractibility, impulsivity, hyperactivity and forgetfulness were linked to decreased frontal and temporal grey matter and also caudate and cerebellar volumes (Arnsten 2006). Excluding changes in volume, studies of cortical development also showed a decrease in cortical thickness (Batty et al. 2010) and a marked delay in brain maturation where the grey matter peaks were about 3 years later, most prominent in prefrontal regions important in the control of cognitive processes, than in healthy controls (Shaw et al. 2006, Shaw et al. 2007). In ADHD patients, DTI studies have revealed developmental changes in cortical white matter pathways in prefrontal regions and also in the pathways that surround the basal ganglia and cerebellum reflecting decreased myelination of axons (D'Agati et al. 2010). Growing evidence points to the fronto-striatal network involving lateral prefrontal cortex, dorsal anterior cingulate cortex, the caudate nucleus and putamen as well as fronto-parietal network as a likely contributor to the pathophysiology of ADHD (Bush et al. 2005). Neurobiological dysfunction of the circuits within the prefrontal cortex, namely dorsal fronto-striatal, orbitofronto-striatal and fronto-cerebellar can lead to the symptoms of ADHD, such as impulsive and inattentive behavior. Functionally, dorsal fronto-striatal circuitry is linked to cognitive control, whereas circuits between striatum and orbitofrontal cortex are related to reward and motivation (Durston et al. 2011). Prefrontal cortex dysfunction results in reduced ability to exercise control (Casey et al. 2007). Dysfunction of ventral striatum can lead to deficits in motivation and reward processing, whereas dysfunction in dorsal striatum can lead to problems with ability to predict what events will occur (Scheres et al. 2007, Plichta et al. 2009). The frontocerebellar circuits are implicated in timing and building temporal expectations and its dysfunction is related to problems of ability to predict when events will occur (Hoekzema et al. 2010). In addition, connections between the prefrontal cortex and amygdala have been suggested to play a role in ADHD, in particular, fronto-amygdalar circuits could be involved in assignment of emotional valence to events and also inputs from amygdala can 
influence the recruitment of prefrontal control (Durston et al. 2011). It is assumed that dysregulated functional communications in these networks are the cause of the behavioral dysfunction in ADHD diagnosis (Nagel et al. 2011).

It is suggested that hyperactivity-impulsive symptoms are associated with changes in the striatum and its connections (van Ewijk et al. 2012). The striatum includes the nucleus accumbens that forms a network with orbitofrontal cortex and anterior cingulate cortex associated with reward processing and motivational control, nucleus caudate facilitating cognitive control via connections with dorsolateral prefrontal cortex and the putamen regulating motor function as well as cognitive control (Oldehinkel et al. 2016). According to recent evidence, putamen and caudate may be functionally divided into smaller subregions (Choi et al. 2012). Investigation of putamen and caudate subregions functional connectivity might detect ADHD-related effects that cannot be revealed when the putamen and caudate are determined as homogenous regions. Specifically, the putamen is divided into an anterior region connected to pre-supplementary motor area, anterior cingulate cortex associated with learning new movements, and a posterior region linked to primary and secondary motor areas and this brain area is related to execution of skilled movements. The caudate is also divided into ventral region connected to prefrontal cortex, anterior cingulate cortex and amygdala to exert cognitive control over emotional loops, and dorsal region connected to prefrontal cortex, motor cortex and parietal cortex associated with cognitive control over actionbased networks. In the latest study, Oldehinkel et al. (2016) observed that functional connectivity of the ventral caudate and posterior putamen networks increased with raised ADHD symptoms scores - inattention and hyperactivity/impulsivity. Furthermore, increased functional connectivity of posterior putamen with motor cortex and cerebellum results in decreased motor performance. They also found out increased functional connectivity of ventral caudate and posterior putamen with occipital cortex as a function of increased inattention that could be explained in the context of interactions between putamen, caudate, occipital cortex and attention networks which are aimed at sustaining attention to relevant stimuli while inhibiting attention to irrelevant stimuli (Shulman et al. 2009, Oldehinkel et al. 2016).

In ADHD, the present findings suggest that the superior longitudinal fasciculus (SLF) is dysfunctional
(Tomasi and Volkow 2012, Franzen et al. 2013). The SLF is a large bundle of white matter in each cerebral hemisphere that connects the parietal, temporal and occipital lobes with ipsilateral frontal cortices. There are four subcomponents of the SLF (SLF I, SLF II, SLF III and SLF IV also called arcuate fasciculus) with different functional contributions to behavior. SLF I connects the medial and dorsal part of the frontal lobe with the cingulate and cingulum of the superior and medial parietal cortex. The SLF II connects the middle frontal gyrus and the postcentral gyrus of the parietal lobe and provides information on visual space and visuo-motor function contributing to spatial attention. The SLF III connects the rostral part of the inferior parietal lobule with the middle frontal gyrus, the inferior frontal gyrus and the frontal lobe and is associated with language articulation. The SLF IV connects the superior temporal gyrus and the ventrolateral prefrontal cortex that modulates language functions and audio-spatial information (Gehricke et al. 2017). The brain imaging study revealed a dysfunctional coupling in parts of the SLF II resulted in saccadic abnormalities that have been found in children with ADHD (Franzen et al. 2013, Matsuo et al. 2015).

In the context of other ADHD symptoms, the present findings suggest that the cortico-limbic circuitry connecting the amygdala with the thalamus and orbital frontal cortex responsible for emotional learning and behavioral regulation is dysfunctional resulting in dysfunctional motivation, emotionality and impulsivity major contributors of the disruptive behaviors in ADHD individuals (Gehricke et al. 2017). The involvement of the SLF and cortico-limbic areas at the brain circuitry level may suggest audio-visual, motivational and emotional dysfunctions in ADHD. Just because, investigating the SLF and cortico-limbic networks may be a novel research direction for better understanding of the underlying mechanisms of ADHD (Gehricke et al. 2017). The major neuroimaging findings in ADHD are summarized in the Table 1.

\section{Neurophysiology and neurochemistry of ADHD}

From neurophysiological point of view, the specific abnormalities detectable in ADHD are closely related to the clinical manifestations of this disorder. Some authors, e.g. Sterman (2000) suggested that ADHD is formed as a consequence of biochemical disturbance in 
prefrontal cortex or associated areas resulting in an inadequate cognitive or behavioral response and reduced attention and control. More than $90 \%$ of children suffering from ADHD show changes in electroencephalography (EEG) activity (Sterman 2000). Due to EEG research, the frequency bands of the most interest in ADHD are theta, beta and alpha, alone or compared to each other (theta/beta ratio). Theta band activity reflects drowsiness or "cortical slowing" in a resting state. Beta band activity accompanies mental activity and concentration. Alpha band activity is observed during eyes-closed resting condition and is negatively associated with central nervous system arousal (Loo and Makeig 2012). In the past, EEG was used to study children with behavioral problems (many of whom could be diagnosed as ADHD today) with the first reports indicating fronto-central EEG slowing (Jasper et al. 1938). Previous research findings suggested that children diagnosed with ADHD exhibit increased fronto-central theta activity during resting state conditions indicating decreased cortical activity associated with underarousal (Chabot and Serfontein 1996, Di Lazzaro et al. 1998, Clarke et al. 2001, Hobbs et al. 2007). According to elevated theta levels and the general association of the beta band activity with attentional arousal, the ratio of theta to beta power during eyes-open or -closed resting conditions has also been reported to be higher in ADHD individuals (Monastra et al. 2001). Taken together, the increases in the theta band activity and also in the theta/beta ratio are the two most reliable EEG findings in ADHD (Loo and Makeig 2012). However, more recent studies failed to replicate these findings, showing no significant differences in the theta power in ADHD compared to healthy controls (Loo et al. 2009, Ogrim et al. 2012, Liechti et al. 2013, Poil et al. 2014, Giertuga et al. 2017). In addition, majority of ADHD studies reported reduced activity in alpha and beta band activities linked to cortical hypoarousal (Di Lazzaro et al. 1998, Clarke et al. 2001, Loo et al. 2009). However, several independent studies identified a subgroup of ADHD children with increased frontal beta band power. This ADHD subgroup is mostly diagnosed as ADHD combined type exhibiting more delinquent behaviors and having a lower intelligence score compared to controls and ADHD children exhibiting decreased beta band activity (Clarke et al. 2002, Clarke et al. 2011).

Table 1. Neuroimaging findings in ADHD

\begin{tabular}{|c|c|c|}
\hline Study, year & Method & Main findings \\
\hline Castellanos et al. 2002 & MRI & Total cerebral and cerebellar volume reduction \\
\hline Valera et al. 2007 & MRI & $\begin{array}{l}\text { Total cerebral volume reduction, volumetric differences in cerebellar regions, } \\
\text { splenium of the corpus callosum and right caudate }\end{array}$ \\
\hline Elison-Wright et al. 2008 & MRI & Gray matter reduction in the right putamen/globus pallidus region \\
\hline Nakao et al. 2011 & MRI & Global reductions in gray matter volumes robustly localized in the basal ganglia \\
\hline Emond et al. 2009 & fMRI & $\begin{array}{l}\text { Reduction in total cerebral volume, the prefrontal cortex, the basal ganglia, the } \\
\text { dorsal anterior cingulate cortex, the splenium of corpus callosum and the } \\
\text { cerebellum } \\
\text { Hypoactivation of the dorsal anterior cingulate cortex, the frontal cortex and the } \\
\text { basal ganglia }\end{array}$ \\
\hline Arnsten 2006 & fMRI & $\begin{array}{l}\text { Decreased frontal and temporal gray matter } \\
\text { Decreased caudate and cerebellar volume }\end{array}$ \\
\hline Batty et al. 2010 & fMRI & Decreased cortical thickness \\
\hline Shaw et al. 2006, 2007 & fMRI & Marked delay in brain maturation mainly in prefrontal regions \\
\hline D'Agati et al. 2010 & DTI & $\begin{array}{l}\text { Developmental changes in cortical white matter pathways in prefrontal regions, } \\
\text { the basal ganglia and cerebellum }\end{array}$ \\
\hline Nagel et al. 2011 & DTI & $\begin{array}{l}\text { White matter microstructural abnormalities in bilateral temporo-occipital and } \\
\text { corona radiata, left cerebellar and right fronto-parietal pathways }\end{array}$ \\
\hline Durston 2011 & DTI & Dysregulated fronto-striatal, orbito-fronto-striatal and fronto-cerebellar circuits \\
\hline Gehricke et al. 2017 & DTI & Dysfunctional superior longitudinal fasciculus and cortico-limbic areas \\
\hline
\end{tabular}


Regarding alpha band activity, recent study reported no significant differences for children suffering from ADHD, but adults diagnosed with ADHD combined type showed significantly reduced alpha activity in comparison with controls (Loo et al. 2010). Moreover, Prihodova et al. (2012) revealed no specific changes in ADHD sleep microstructure.

Furthermore, the ADHD is associated with several dysfunctional neurotransmitter systems. In particular, the noradrenergic and dopaminergic systems are involved in ADHD pathophysiology. The noradrenergic system has been associated with the modulation of higher cortical functions such as attention, vigilance and executive function. Moreover, noradrenergic activation affects the attention mainly by the maintenance of arousal (Biederman and Spencer 1999). Arnsten et al. (1999) supported a crucial role of noradrenergic functioning in higher cortical activity by suggestion that high levels of catecholamine release disrupt cognitive functions of the prefrontal cortex. In particular, the action of norepinephrine (NE) and dopamine (DA) is most studied in prefrontal cortex (PFC). PFC is essential for attention and behavioral regulation and requires an optimal catecholamine environment. Both catecholamines have an inverted $\mathrm{U}$ influence on prefrontal cortex function, whereby too much and also too little NE or DA impairs prefrontal cortex cognitive abilities. Modest levels of NE improve PFC function through its action at postsynaptic $\alpha 2 \mathrm{~A}$ receptors, but high levels of NE impair working memory through actions at $\alpha 1$ and $\beta 1$ receptors. Similar to NE, optimal DA D1-receptor stimulation is essential to PFC function, while high levels of DA release also impair working memory. Genetic alterations in catecholamine pathways may contribute to dysregulation of PFC circuits in ADHD (Brennan and Arnsten 2008).

Moreover, in ADHD children, anticipatory dopamine cell firing is diminished, which is termed dopamine transfer deficit. According to this theory, children suffering from ADHD would have a delayed dopamine signal at the cellular level compared to the normal children with immediate dopamine signal and this can explain abnormal sensitivity to delay of reinforcement (Tripp and Wickens 2008). Recently, the dopamine transfer deficit theory has been also supported by fMRI studies that showed reduced responsiveness of the ventral striatum to rewards relative to controls (Scheres et al. 2007, Plichta et al. 2009). Although the mechanism of DTD is unknown, it could explain several
ADHD symptoms. The several DSM-V symptoms of inattention such as "often fails to give close attention to details or makes careless mistakes in schoolwork, work or other activities", "often has difficulty sustaining attention in tasks or play activities", and "is often easily distracted by extraneous stimuli" may be due to failure of anticipatory dopamine cell firing leading to control of behavior by actual instances of reinforcement rather than predicted reinforcement. Other inattention symptoms like "often does not follow through on instructions and fails to finish schoolwork, chores or duties in the workplace" and "often avoids, dislikes or is reluctant to engage in tasks that require sustained mental effort" can be explained by failure of conditioned reinforcers leading to increased sensitivity to delay of reinforcement. This theory also explains few DSM-V symptoms of hyperactivity and impulsivity e.g. "often leaves seat in classroom or in other situation in which remaining seated is expected" explained by a lack of effective reinforcement due to smaller activity of dopamine neurons. The other symptoms such as "often has difficulty awaiting turn", "often blurts out answers before questions have been completed" and "often interrupts or intrudes on others" may be interpreted by a failure of the transfer of dopamine cell firing activity in response to cues predicting reinforcement (Tripp and Wickens 2009). Beside the dopaminergic and adrenergic system, serotonergic and cholinergic pathways may be involved in ADHD as well (Prince 2008).

\section{Genetic basis for ADHD}

ADHD is a disorder with high heritability ranging from 60 to $90 \%$. Genetic factors play an important role in the pathophysiology of ADHD, but the mechanism of action is not completely understood (Wood and Neale 2010, Hawi et al. 2015). In recent review, Hawi et al. (2015) highlighted several candidate genes with significant association with ADHD. Products of these genes are involved in neurotransmission, with one half playing an important role in monoaminergic function, namely dopamine and serotonin transporters (SLC6A3, SLC6A4), D4, D5 and serotonin receptors (DRD4, DRD5, 5HT1B) (Cook et al. 1995, LaHoste et al. 1996, Daly et al. 1999, Seeger et al. 2001, Hawi et al. 2002). Other risk loci were mapped in genes involved in synaptic transmission (SNAP25, NOS1, LPHN3, GIT1) (Brophy et al. 2002, Reif et al. 2009, Arcos-Burgos et al. 2010, Won et al. 2011). In addition, recent study 
indicated that $S L C 2 A 3$ variation, the gene encoding glucose transporter-3 (GLUT3), may result in neurocognitive deficits (in working memory and cognitive response control) known to contribute to ADHD risk. GLUT3 plays a crucial role in the cerebral glucose metabolism, providing energy for the activity of neurons, which, in turn, moderates the excitatoryinhibitory balance impacting both brain development and activity-dependent neural plasticity (Merker et al. 2017). Despite growing number of genome-wide association studies (GWAS) in child and adult ADHD, there has been limited success in showing significant genome-wide associations. Only two loci within the $C D H 13$ and the GFOD1 genes have exceeded the critical significance threshold for genome-wide associations with quantitative attributes of ADHD (Lasky-Su et al. 2008). CDH13 encodes cadherin-13, a calcium-dependent protein important in cell-cell adhesion and neural cell growth, expressed in the cerebral cortex (Neale et al. 2010). Moreover, single nucleotide polymorphisms within CDH13 have been linked to working memory deficits and hyperactivity/impulsivity in ADHD individuals (AriasVásquez et al. 2011, Salatino-Oliveira et al. 2015). GFOD1 is a gene expressed in the brain and involved in electron transport, but its implications for ADHD are less known (Franke et al. 2009). The selected candidate genes are summarized in the Table 2.

Table 2. Selected candidate genes implicated in ADHD

\begin{tabular}{|c|c|c|}
\hline & Gene product or function & Method(s) used to show association \\
\hline$S L C 6 A 3(D A T)$ & Dopamine re-uptake, transporter & Candidate gene (Cook et al. 1995) \\
\hline DRD4 & Dopamine D4 receptor & Candidate gene (LaHoste et al. 1996) \\
\hline DRD5 & Dopamine D5 receptor & Candidate gene (Daly et al. 1999) \\
\hline SLC6A4 & Serotonin re-uptake, transporter & Candidate gene (Seeger et al. 2001) \\
\hline $5 H T 1 B$ & Serotonin receptor & Candidate gene (Hawi et al. 2002) \\
\hline SNAP25 & $\begin{array}{l}\text { Synaptosomal-associated protein } 25 \text {, } \\
\text { neurotransmission }\end{array}$ & Candidate gene (Brophy et al. 2002) \\
\hline NOS1 & $\begin{array}{l}\text { Nitric oxide synthase, neurotransmission, } \\
\text { neuroplasticity }\end{array}$ & Candidate gene (Reif et al. 2009) \\
\hline$L P H N 3$ & $\begin{array}{l}\text { Latrophilin } 3 \text {, GPCR, cell adhesion, signal } \\
\text { transduction }\end{array}$ & Linkage study ( Arcos-Burgos et al. 2010) \\
\hline GIT1 & $\begin{array}{l}\text { GPCR kinase, vesicle trafficking, cell adhesion, } \\
\text { cell migration }\end{array}$ & Candidate gene (Won et al. 2011) \\
\hline$S L C 2 A 3$ & Glucose-transporter 3 & Candidate gene (Merker et al. 2017) \\
\hline $\mathrm{CDH13}$ & Cell-cell adhesion and neural cell growth & GWAS (Lasky-Su et al. 2008) \\
\hline & & $\begin{array}{l}\text { Candidate gene (Arias-Vásquez et al. } \\
\text { 2011, Salatino-Oliveira et al. } 2015 \text { ) }\end{array}$ \\
\hline GFOD1 & $\begin{array}{l}\text { Glucose-fructose oxidoreductase-domain } \\
\text { containing } 1 \text {, electron transport }\end{array}$ & GWAS (Lasky-Su et al. 2008) \\
\hline
\end{tabular}

GPCR: G protein-coupled receptor, GWAS: genome-wide association studies

\section{Central autonomic regulation}

Autonomic nervous system (ANS) represents an important regulatory system involved in attention and self-regulation by influencing physiological arousal. Physiologically, this regulatory mechanism plays crucial role in adaptation to changing internal and external environment, however, after exposition to long-term, repetitive mental stress associated with altered sympathetic regulation, it may become maladaptive (Mestanik et al. 2015). In this context, interindividual differences in physiological measures (e.g. sympathovagal dynamic balance) and in the responsivity to various challenges of the stress response system may contribute to the risk for mental disorders (Tonhajzerova and Mestanik, 2017). Our previous studies revealed discrete 
ANS abnormalities in various psychiatric disorders (e.g. depression, autism) and also changes in ADHD-linked autonomic balance towards the cardiac vagal deficiency associated with sympathetic dominance using heart rate variability linear and nonlinear analysis (Tonhajzerova et al. 2009, Tonhajzerová et al. 2014, Bujnakova et al. 2016, Mestanikova et al. 2017). In this aspect, the inhibitory function of prefrontal cortex on subcortical structures including brainstem sympathoexcitatory circuits plays a crucial role in flexibility and adaptability (Thayer and Lane 2009). With regard to neurobiological basis of ADHD, delayed prefrontal cortical maturation combined with a lack of physiological autonomic development in ADHD children, as noted in recent studies (Buchhorn et al. 2012), could contribute to dominance of subcortical sympathoexcitatory regions resulting in ADHD symptoms such as inattention (Tonhajzerova et al. 2016). However, the question related to noninvasive indices reflecting central autonomic regulatory network in ADHD is unresolved. Thus, the monitoring of the spontaneous eye movements using eye-tracking and studying pupillary light reflex by using pupillometry as potential noninvasive novel methods reflecting changes in central autonomic activity are discussed in the following paragraphs.

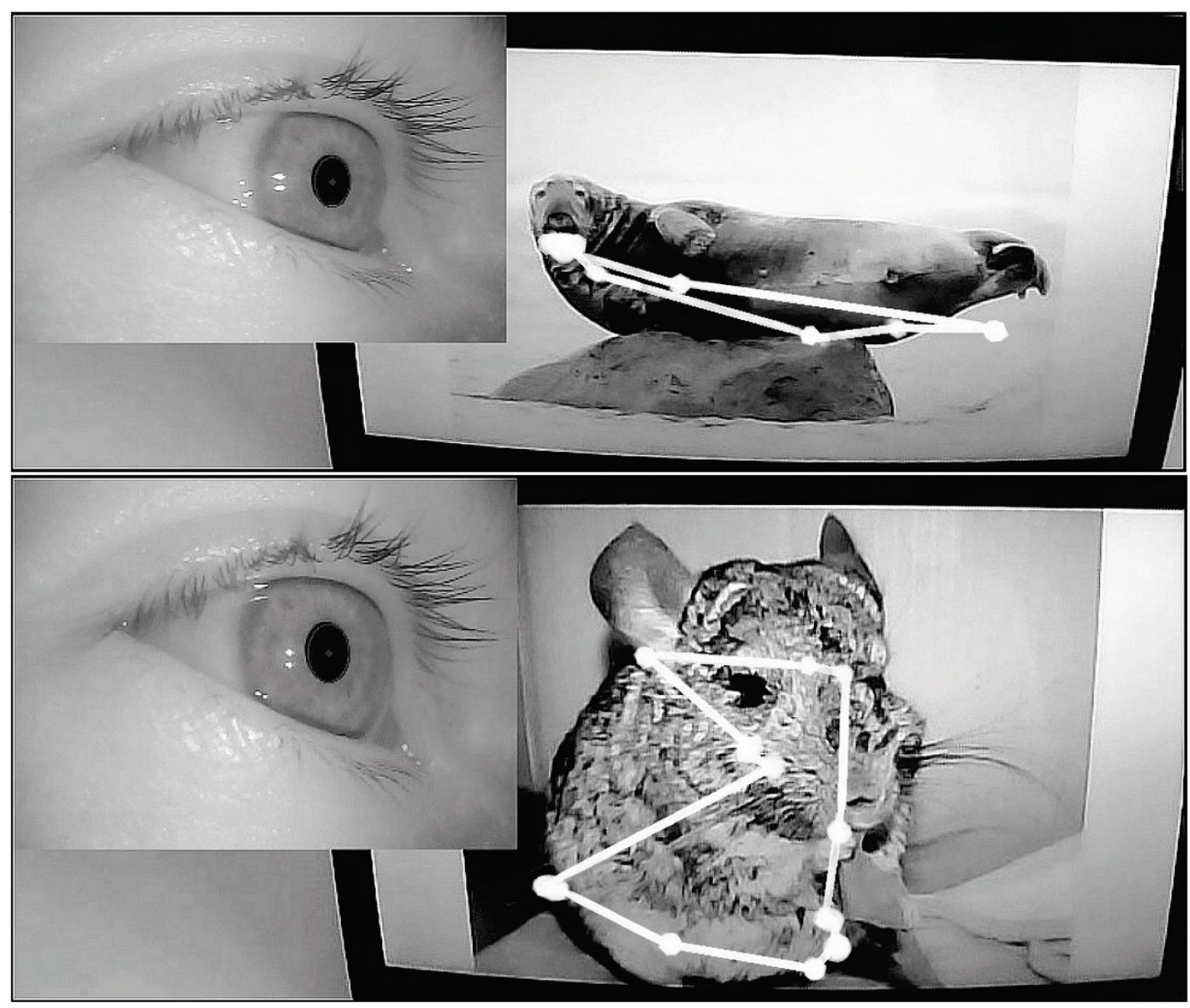

Fig. 1. Gaze polyline during 6s object tracking (Department of Physiology and Biomedical Center Martin; device: Mobile Eye-tracking Headset Pupil Labs, Germany).

\section{Visual attention indexed by eye-tracking}

Eye-tracking is a method used to register eye movement to find the direction and targets of a person's gaze (Fig. 1). Information captured by eye-tracking methods is useful to reveal abnormalities in eye functioning but also to conduct cognitive studies focused on learning about people's emotions and intentions (Harezlak and Kasprowski 2017). Despite eye-tracking intense research, it is still a very challenging task due to significant pupil reflectivity and variability of the shape and openness of the eye (Demjen et al. 2011). Eye movement, the most studied domain in cognitive neuroscience, as a result of interaction between various 
cognitive processes may provide knowledge about behavioral processes underlying mental disorders in children (Rommelse et al. 2008). Changes in saccadic eye movement appear to be involved in psychiatric disorders (Jagla 2016). Despite the fact that the basic brain mechanisms of saccadic eye movement paradigms are well documented in adults, this question is unclear in children and adolescents (Carlson 2000, Karatekin 2007). Emerging evidence shows that small involuntary eye movements, saccades and microsaccades, are a promising tool for investigation of cognitive processes impaired in ADHD individuals. Various paradigms have been used to investigate eye movements, the most commonly discussed types are saccadic paradigms, namely, antisaccades (AS), visually guided saccades (VGS), memory guided saccades (MGS) and smooth pursuit eye movements (SPEM). These paradigms are used to estimate basic oculomotor behavior and to investigate executive functions like inhibition and working memory (Rommelse et al. 2008). In AS, visual onset is presented and the participants are required to make an eye movement away from the onset location to its mirror position (Everling and Fischer 1998). Successful performance of this task requests the top-down inhibition of a reflexive saccade to the onset location and the execution of a voluntary eye movement to the mirror position. Typical measures in AS are the number of directional errors reflecting a failure to suppress an inappropriate response due to problems with top-down regulation and saccade latency (Rommelse et al. 2008). AS activate the frontal eye fields, dorsolateral prefrontal cortex (DLPFC) and the supplementary eye fields (Everling and Munoz 2000). The majority of AS studies found an increased number of directional errors indicating a failure of top-down regulation in children with ADHD compared to controls (Karatekin and Asarnow 1998, Klein et al. 2003, O’Driscoll et al. 2005, Habeych et al. 2006). In MGS, the observers are required to look at a central fixation point. During this fixation, a target appears in the peripheral visual field and the participant is not allowed to make a saccade towards this target but has to remember its location. When the fixation point disappears, the observer is requested to make a saccade towards the memorized location. Typical measures are accuracy indicating the participant's ability to remember the location of the target, anticipatory errors reflecting inhibitory problems and saccade latency (Rommelse et al. 2008). MGS activate DLPFC, anterior cingulate cortex and supplementary eye field (Sawaguchi and Iba 2001, Ettinger et al. 2005). Studies reported more anticipatory errors in MGS indicating problems with inhibitory control in children with ADHD compared to controls (Ross et al. 1994, Castellanos et al. 2000, Mostofsky et al. 2001). Furthermore, more intrusive saccades, inappropriate eye movements, have been found in ADHD and are also reported in a variety of tasks, e.g. the go/nogo task (Castellanos et al. 2000). All these findings indicate a reduction in ability to suppress unwanted saccades and to control voluntary behavior and support the hypothesis of inhibition deficits in children with ADHD (Rommelse et al. 2008).

\section{Pupillary light reflex indexed by pupillometry}

Pupillometry as a simple, non-invasive method of pupil's diameter measuring provides important information about dynamic balance between sympathetic and parasympathetic nervous system. Changes of the pupil size are determined by the tone of two opposing smooth muscles, the dilatator and the constrictor. Pupillary constriction is mediated by the action of the sphincter muscle under parasympathetic control whereas pupillary dilation is mediated by the action of the dilatator under sympathetic control or by inhibition of constrictor (Laeng et al. 2012). The balance of activity in sympathetic and parasympathetic branches depends on several factors, such as genetic influences, age, accommodative state and light conditions and after their standardization pupil's diameter measurement can be used for identifying deficits in both of the autonomic nervous system branches (Bremner 2009). Therefore, the pupillary light reflex provides an optimal model for investigating central autonomic regulation/dysregulation in mental disorders (Mestanikova et al. 2017).

With respect to ADHD, there are studies examining the autonomic regulation/dysregulation based on heart rate variability (Crowell et al. 2006, Tonhajzerova et al. 2009) and electrodermal activity (Shibagaki et al. 1993), but lack of those based on measurement of pupil diameter. Pupillary light reflex, the pupillary constriction in response to light, is regulated at the subcortical level. Light falling on the retina activates the pretectal olivary nuclei consequent activation of the Edinger-Westphal region, the parasympathetic center for pupillary constriction, resulting in generation of action potentials through the oculomotor nerves innervating the ciliary ganglion and leading to the activation of the 
constrictor muscle resulting in pupil constriction (Thompson 1992, Güler et al. 2008, McDougal and Gamlin 2015). Moreover, the Edinger-Westphal region receives inhibitory input from the subcortical brain structure locus coeruleus. Specifically, the activity of parasympathetic oculomotor center is inhibited by the sympathetic-linked locus coeruleus. Reduction in this inhibitory input can lead to pupil constriction (AstonJones and Cohen 2005, Wilhelm et al. 2002). On the contrary, higher sympathetic nervous activity excites the neural inhibitory mechanism on Edinger-Westphal nucleus resulting in pupillary dilatation (Laeng et al. 2012). In addition, the Edinger-Westphal region is also modulated by inhibitory inputs from descending cortical pathways. Cognitive load associated with frontal and prefrontal cortical functioning mediated by direct cortical and indirect cortico-thalamo-hypothalamic pathways contributes to this inhibitory process (Steinhauer and Hakerem 1992, Steinhauer et al. 2004). Previously, smaller pupil dilation to visual stimulus was observed in the children with minimal brain dysfunction compared to controls (Zahn et al. 1978). Recently, Kara et al. (2013) found no significant differences between ADHD and healthy children in pupil diameters. Despite the fact that patients in our research showed altered PLR parameters specifically smaller percentual change of constriction amplitude associated with slower average and maximum constriction velocity indicating a deficient parasympathetic activity (Fig. 2), the further research is needed to elucidate this question.

\section{Control subject}
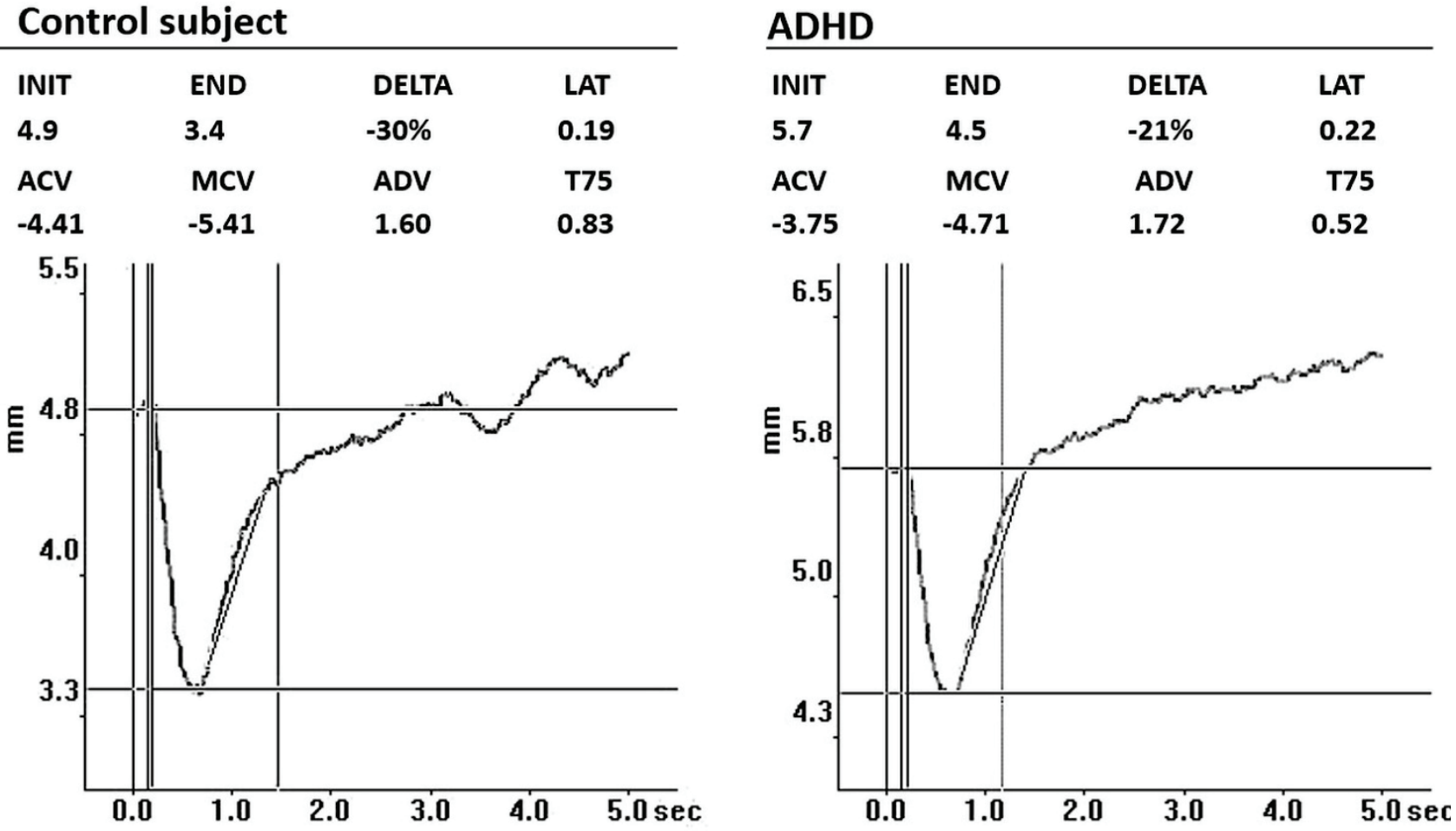

Fig. 2. Pupillary light reflex parameters in healthy control and patient with ADHD (Department of Physiology and Biomedical Center Martin; device: Pupillometer PLR-2000, NeurOptics, USA). INIT: diameter of the pupil before application of light stimulus (mm), END: diameter of the pupil after illumination at the peak of the constriction $(\mathrm{mm})$, DELTA: percentual change of the pupil diameter during constriction, LAT: time of the onset of the constriction after application of light stimulus (latency), ACV: average constriction velocity $(\mathrm{mm} / \mathrm{s})$, MCV: maximum constriction velocity (mm/s), ADV: average dilatation velocity ( $\mathrm{mm} / \mathrm{s})$.

\section{Conclusion}

The ADHD diagnosis is associated with widespread macrostructural and microstructural changes in central nervous system, affecting mainly the frontal, basal ganglia, anterior cingulate cortex, temporal, and occipito-parietal brain regions. Moreover, convergent data from neuroimaging, neuropsychology, neurochemical and genetics studies point to the involvement of the multiple circuits in the pathophysiology of ADHD. Functional neuroimaging has shown widespread dysfunction in neural systems involving the prefrontal, striatal and parietal regions. Dysfunction of various neurotransmitter systems involved in ADHD is supported by molecular genetic studies. The study of central autonomic regulation using 
novel methods - PLR and eye-tracking can help us to elucidate neuropathophysiology of ADHD.

\section{Conflict of Interest}

There is no conflict of interest.

\section{Acknowledgements}

This work was supported by the Slovak Scientific Grant Agency under grant VEGA 1/0044/18, the project „Biomedical Center Martin“ ITMS code: 26220220187, co-financed from European Union (EU) sources and the project „European Centre of Excellence for Perinatological Research“ no. 26220120036.

\section{References}

ARCOS-BURGOS M, JAIN M, ACOSTA MT, SHIVELY S, STANESCU H, WALLIS D, DOMENÉ S, VÉLEZ JI, KARKERA JD, BALOG J, BERG K, KLETA R, GAHL WA, ROESSLER E, LONG R, LIE J, PINEDA D, LONDOÑO AC, PALACIO JD, ARBELAEZ A, LOPERA F, ELIA J, HAKONARSON H, JOHANSSON S, KNAPSKOGG PM, HAAVIK J, RIBASES M, CORMAND B, BAYES M, CASAS M, RAMOS-QUIROGA JA, HERVAS A, MAHER BS, FARAONE SV, SEITZ C, FREITAG CM, PALMASON H, MEYER J, ROMANOS M, WALITZA S, HEMMINGER U, WARNKE A, ROMANOS J, RENNER T, JACOB C, LESCH KP, SWANSON J, VORTMEYER A, BAILEY-WILSON JE, CASTELLANOS FX, MUENKE M: A common variant of the latrophilin 3 gene, LPHN3, confers susceptibility to ADHD and predicts effectiveness of stimulant medication. Mol Psychiatry 15: 1053-1066, 2010.

ARIAS-VÁSQUEZ A, ALTINK ME, ROMMELSE NN, SLAATS-WILLEMSE DI, BUSCHGENS CJ, FLIERS EA, FARAONE SV, SERGEANT JA, OOSTERLAAN J, FRANKE B, BUITELAAR JK: $C D H 13$ is associated with working memory performance in attention deficit/hyperactivity disorder. Genes Brain Behav 10: 844-851, 2011.

ARNSTEN AF, MATHEW R, UBRIANI R, TAYLOR JR, LI BM: Alpha-1 noradrenergic receptor stimulation impairs prefrontal cortical cognitive function. Biol Psychiatry 45: 26-31, 1999.

ARNSTEN AF: Fundamentals of attention-deficit/hyperactivity disorder: circuits and pathways. J Clin Psychiatry 67: 7-12, 2006.

ASTON-JONES G, COHEN JD: An integrative theory of locus coeruleus-norepinephrine function: Adaptive Gain and Optimal Performance. Ann Rev Neurosci 28: 403-450, 2005.

BARKLEY RA: Behavioral inhibition, sustained attention, and executive functions: constructing a unifying theory of ADHD. Psychol Bull 121: 65-94, 1997.

BATTY MJ, LIDDLE EB, PITIOT A, TORO R, GROOM MJ, SCERIF G, LIOTTI M, LIDDLE PF, PAUS T, HOLLIS C: Cortical gray matter in attention-deficit/hyperactivity disorder: a structural magnetic resonance imaging study. J Am Acad Child Adolesc Psychiatry 49: 229-238, 2010.

BENARROCH EE: The central autonomic network: functional organization, dysfunction, and perspective. Mayo Clin Proc 68: 988-1001, 1993.

BIEDERMAN J, FARAONE SV: Attention-deficit hyperactivity disorder. Lancet 366: 237-248, 2005.

BIEDERMAN J, SPENCER T: Attention-deficit/hyperactivity disorder (ADHD) as a noradrenergic disorder. Biol Psychiatry 46: 1234-1242, 1999.

BREMNER F: Pupil evaluation as a test for autonomic disorders. Clin Auton Res 19: 88-101, 2009.

BRENNAN AR, ARNSTEN AF: Neuronal mechanisms underlying attention deficit hyperactivity disorder. Ann NY Acad Sci 1129: 236-245, 2008.

BROPHY K, HAWI Z, KIRLEY A, FITZGERALD M, GILL M: Synaptosomal-associated protein 25 (SNAP-25) and attention deficit hyperactivity disorder (ADHD): evidence of linkage and association in the Irish population. Mol Psychiatry 7: 913-917, 2002.

BUCHHORN R, CONZELMANN A, WILLASCHEK C, STÖRK D, TAURINES R, RENNER TJ: Heart rate variability and methylphenidate in children with ADHD. Atten Defic Hyperact Disord 4: 85-91, 2012.

BUJNAKOVA I, ONDREJKA I, MESTANIK M, VISNOVCOVA Z, MESTANIKOVA A, HRTANEK I, FLESKOVA D, CALKOVSKA A, TONHAJZEROVA I: Autism Spectrum disorder is associated with autonomic underarousal. Physiol Res 65 (Suppl 5): S673-S682, 2016. 
BUSH G, VALERA EM, SEIDMAN LJ: Functional neuroimaging of attention-deficit/hyperactivity disorder: a review and suggested future directions. Biol Psychiatry 57: 1273-1284, 2005.

CARLSON GA: Phenomenology and outcome of subjects with early- and adult-onset psychotic mania. Am J Psychiatry 157: 213-219, 2000.

CASEY B, NIGG JT, DURSTON S: New potential leads in the biology and treatment of attention deficit-hyperactivity disorder. Curr Opin Neurol 20: 119-124, 2007.

CASTELLANOS FX, LEE PP, SHARP W, JEFFRIES NO, GREENSTEIN DK, CLASEN LS, BLUMENTHAL JD, JAMES RS, EBENS CL, WALTER JM, ZIJDENBOS A, EVANS AC, GIEDD JN, RAPOPORT JL: Developmental trajectories of brain volume abnormalities in children and adolescents with attentiondeficit/hyperactivity disorder. JAMA 288: 1740-1748, 2002.

CASTELLANOS FX, MARVASTI FF, DUCHARME JL, WALTER JM, ISRAEL ME, KRAIN A, PAVLOVSKY C, HOMMER DW: Executive function oculomotor tasks in girls with ADHD. $J$ Am Acad Child Adolesc Psychiatry 39: 644-650, 2000.

CHABOT RJ, SERFONTEIN G: Quantitative electroencephalographic profiles of children with attention deficit disorder. Biol Psychiatry 40: 951-963, 1996.

CHOI EY, YEO BT, BUCKNER RL: The organization of the human striatum estimated by intrinsic functional connectivity. J Neurophysiol 108: 2242-2263, 2012.

CLARKE AR, BARRY RJ, DUPUY FE, HECKEL LD, MCCARTHY R, SELIKOWITZ M, JOHNSTONE SJ: Behavioural differences between EEG-defined subgroups of children with Attention-Deficit/Hyperactivity Disorder. Clin Neurophysiol 122: 1333-1341, 2011.

CLARKE AR, BARRY RJ, MCCARTHY R, SELIKOWITZ M: EEG-defined subtypes of children with attentiondeficit/hyperactivity disorder. Clin Neurophysiol 112: 2098-2105, 2001.

CLARKE AR, BARRY RJ, MCCARTHY R, SELIKOWITZ M: EEG Analysis of children with AttentionDeficit/Hyperactivity Disorder and comorbid reading disabilities. J Learn Disabil 35: 276-285, 2002.

COOK EH, STEIN MA, KRASOWSKI MD, COX NJ, OLKON DM, KIEFFER JE, LEVENTHAL BL: Association of attention-deficit disorder and the dopamine transporter gene. Am J Hum Gen 56: 993-998, 1995.

CROWELL SE, BEAUCHAINE TP, GATZKE-KOPP L, SYLVERS PD, MEAD H, CHIPMAN-CHACON J: Autonomic correlates of attention deficit/hyperactivity disorder and oppositional defiant disorder in preschool children. J Abnorm Psychol 115: 174-178, 2006.

D’AGATI E, CASARELLI L, PITZIANTI MB, PASINI A: Overflow movements and white matter abnormalities in ADHD. Prog Neuropsychopharmacol Biol Psychiatry 34: 441-445, 2010.

DALY G, HAWI Z, FITZGERALD M, GILL M: Mapping susceptibility loci in attention deficit hyperactivity disorder: preferential transmission of parental alleles at DAT1, DBH and DRD5 to affected children. Mol Psychiatry 4: 192-196, 1999.

DEMJEN E, ABOSI V, TOMORI Z: Eye tracking using artificial neural networks for human computer interaction. Physiol Res 60: 841-844, 2011.

DI LAZZARO V, RESTUCCIA D, OLIVIERO A, PROFICE P, FERRARA L, INSOLA A, MAZZONE P, TONALI P, ROTHWELL JC: Magnetic transcranial stimulation at intensities below active motor threshold activates intracortical inhibitory circuits. Exp Brain Res 119: 265-268, 1998.

DOGGETT AM: ADHD and drug therapy: is it still a valid treatment? J Child Health Care 8: 69-81, 2004.

DURSTON S, VAN BELLE J, DE ZEEUW P: Differentiating frontostriatal and fronto-cerebellar circuits in AttentionDeficit/Hyperactivity disorder. Biol Psychiatry 69: 1178-1184, 2011.

ELLISON-WRIGHT I, ELLISON-WRIGHT Z, BULLMORE E: Structural brain change in Attention Deficit Hyperactivity Disorder identified by meta-analysis. BMC Psychiatry 8: 51, 2008.

EMOND V, JOYAL C, POISSANT H: Structural and functional neuroanatomy of attention-deficit hyperactivity disorder (ADHD): L'Encéphale 35: 107-114, 2009.

ETTINGER U, ANTONOVA E, CRAWFORD TJ, MITTERSCHIFFTHALER MT, GOSWANI S, SHARMA T, KUMARI V: Structural neural correlates of prosaccade and antisaccade eye movements in healthy humans. NeuroImage 24: 487-494, 2005.

EVERLING S, FISCHER B: The antisaccade: a review of basic research and clinical studies. Neuropsychologia 36: 885-899, 1998. 
EVERLING S, MUNOZ DP: Neuronal correlates for preparatory set associated with pro-saccades and anti-saccades in the primate frontal eye field. J Neurosci 20: 387-400, 2000.

FRANKE B, NEALE BM, FARAONE SV: Genome-wide association studies in ADHD. Human Genet 126: 13-50, 2009.

FRANZEN JD, HEINRICHS-GRAHAM E, WHITE ML, WETZEL MW, KNOTT NL, WILSON TW: Atypical coupling between posterior regions of the default mode network in attention-deficit/hyperactivity disorder: a pharmaco-magnetoencephalography study. J Psych Neurosci 38: 333-340, 2013.

GEHRICKE JG, KRUGGEL F, THAMPIPOP T, ALEJO SD, TATOS E, FALLON J, MUFTULER LT: The brain anatomy of attention-deficit/hyperactivity disorder in young adults - a magnetic resonance imaging study. PLoS One 12: e0175433, 2017.

GIERTUGA K, ZAKRZEWSKA MZ, BIELECKI M, RACICKA-PAWLUKIEWICZ E, KOSSUT M, CYBULSKAKLOSOWICZ A: Age-related changes in resting-state EEG activity in attention deficit/hyperactivity disorder: a cross-sectional study. Front Hum Neurosci 11: 285, 2017.

GÜLER AD, ECKER JL, LALL GS, HAQ S, ALTIMUS CM, LIAO HW, BARNARD AR, CAHILL H, BADEA TC, ZHAO H, HANKINS MW, BERSON DM, LUCAS RJ, YAU KW, HATTAR S: Melanopsin cells are the principal conduits for rod-cone input to non-image-forming vision. Nature 453: 102-105, 2008.

HABEYCH ME, FOLAN MM, LUNA B, TARTER RE: Impaired oculomotor response inhibition in children of alcoholics: The role of attention deficit hyperactivity disorder. Drug and Alcohol Dependence 82: 11-17, 2006.

HAREZLAK K, KASPROWSKI P: Application of eye tracking in medicine: a survey, research issues and challenges. Comput Med Imaging Graph 65: 176-190, 2017.

HAWI Z, CUMMINS TD, TONG J, JOHNSON B, LAU R, SAMARRAI W, BELLGROVE MA: The molecular genetic architecture of attention deficit hyperactivity disorder. Mol Psychiatry 20: 289-297, 2015.

HAWI Z, DRING M, KIRLEY A, FOLEY D, KENT L, CRADDOCK N, ASHERSON P, CURRAN S, GOULD A, RICHARDS S, LAWSON D, PAY H, TURIC D, LANGLEY K, OWEN M, O'DONOVAN M, THAPAR A, FITZGERALD M, GILL M: Serotonergic system and attention deficit hyperactivity disorder (ADHD): a potential susceptibility locus at the 5-HT1B receptor gene in 273 nuclear families from a multi-centre sample. Mol Psychiatry 7: 718-725, 2002.

HOBBS MJ, CLARKE AR, BARRY RJ, MCCARTHY R, SELIKOWITZ M: EEG abnormalities in adolescent males with AD/HD. Clin Neurophysiol 118: 363-371, 2007.

HOEKZEMA E, CARMONA S, TREMOLS V, GISPERT JD, GUITART M, FAUQUET J, ROVIRA M, BIELSA A, SOLIVA JC, TOMAS X, BULBENA A, RAMOS-QUIROQA A, CASAS M, TOBEŃA A, VILARROYA O: Enhanced neural activity in frontal and cerebellar circuits after cognitive training in children with attentiondeficit/hyperactivity disorder. Hum Brain Mapp 31: 1942-1950, 2010.

JAGLA F: Saccadic eye movements as a marker of mental disorders. Physiol Res 65: 365-371, 2016.

JASPER HH, SOLOMON P, BRADLEY C: Electroencephalographic analyses of behavior problem children. $A m J$ Psychiatry 95: 641-658, 1938.

KARA K, KARAMAN D, ERDEM U, CONGOLOGLU MA, DURUKAN I, ILHAN A: Investigation of autonomic nervous system functions by pupillometry in children with attention deficit hyperactivity disorder. Bull Clin Psychopharmacol 23: 49-56, 2013.

KARATEKIN C: Eye tracking studies of normative and atypical development. Develop Rev 27: 238-348, 2007.

KARATEKIN C, ASARNOW RF: Components of visual search in childhood-onset schizophrenia and attentiondeficit/hyperactivity disorder. J Abnorm Child Psychol 26: 367-380, 1998.

KLEIN CH, RASCHKE A, BRANDENBUSCH A: Development of pro- and antisaccades in children with attentiondeficit hyperactivity disorder (ADHD) and healthy controls. Psychophysiol 40: 17-28, 2003.

LAENG B, SIROIS S, GREDEBÄCK G: Pupillometry: A Window to the Preconscious? Perspect Psychol Sci 7: 18-27, 2012.

LAHOSTE GJ, SWANSON JM, WIGAL SB, GLABE C, WIGAL T, KING N, KENNEDY JL: Dopamine D4 receptor gene polymorphism is associated with attention deficit hyperactivity disorder. Mol Psychiatry 1: 121-124, 1996. 
LASKY-SU J, NEALE BM, FRANKE B, ANNEY RJ, ZHOU K, MALLER JB, VASQUEZ AA, CHEN W, ASHERSON P, BUITELAAR J, BANASCHEWSKI T, EBSTEIN R, GILL M, MIRANDA A, MULAS F, OADES RD, ROEYERS H, ROTHENBERGER A, SERGEANT J, SONUGA-BARKE E, STEINHAUSEN HC, TAYLOR E, DALY M, LAIRD N, LANGE C, FARAONE SV: Genome-wide association scan of quantitative traits for attention deficit hyperactivity disorder identifies novel associations and confirms candidate gene associations. Am J Med Genet B Neuropsychiatr Genet 147: 1345-1354, 2008.

LIECHTI MD, VALKO L, MÜLLER UC, DÖHNERT M, DRECHSLER R, STEINHAUSEN HC, BRANDEIS D: Diagnostic value of resting electroencephalogram in attention-deficit/hyperactivity disorder across the lifespan. Brain Topogr 26: 135-151, 2013.

LOO SK, HALE ST, HANADA G, MACION J, SHRESTHA A, MCGOUGH JJ, MCCRACKEN JT, NELSON S, SMALLEY SL: Familial clustering and DRD4 effects on electroencephalogram measures in multiplex families with attention deficit/hyperactivity disorder. J Am Acad Child AdolescPsychiatry 49: 368-377, 2010.

LOO SK, HALE TS, MACION J, HANADA G, MCGOUGH JJ, MCCRACKEN JT, SMALLEY SL: Cortical activity patterns in ADHD during arousal, activation and sustained attention. Neuropsychologia 47: 2114-2119, 2009.

LOO SK, MAKEIG S: Clinical utility of EEG in attention-deficit/hyperactivity disorder: a research update. Neurotherapeutics 9: 569-587, 2012.

MATSUO Y, WATANABE M, TANIIKE M, MOHRI I, KOBASHI S, TACHIBANA M, KOBAYASHI Y, TSUDA Y: Gap effect abnormalities during a visually guided pro-saccade task in children with attention deficit hyperactivity disorder. PloS One 10: e0125573, 2015.

MCDOUGAL DH, GAMLIN PD: Autonomic control of the eye. Compr Physiol 5: 439-473, 2015.

MERKER S, REIF A, ZIEGLER GC, WEBER H, MAYER U, EHLIS AC, CONZELMANN A, JOHANSSON S, MÜLLER-REIBLE C, NANDA I, HAAF T, ULLMANN R, ROMANOS M, FALLGATTER AJ, PAULI P, STREKALOVA T, JANSCH C, VASQUEZ AA, HAAVIK J, RIBASÉS M, RAMOS-QUIROGA JA, BUITELAAR JK, FRANKE B, LESCH KP: $S L C 2 A 3$ single-nucleotide polymorphism and duplication influence cognitive processing and population-specific risk for attention-deficit/hyperactivity disorder. $J$ Child Psychol Psychiatry 58: 798-809, 2017.

MESTANIK M, MESTANIKOVA A, VISNOVCOVA Z, CALKOVSKA A, TONHAJZEROVA I: Cardiovascular sympathetic arousal in response to different mental stressors. Physiol Res 64: 585-594, 2015.

MESTANIKOVA A, ONDREJKA I, MESTANIK M, CESNEKOVA D, VISNOVCOVA Z, BUJNAKOVA I, OPPA M, CALKOVSKA A, TONHAJZEROVA I: Pupillary light reflex is altered in adolescent depression. Physiol Res 66: 277-284, 2017.

MONASTRA VJ, LUBAR JF, LINDEN M: The development of a quantitative electroencephalographic scanning process for attention deficit-hyperactivity disorder: reliability and validity studies. Neuropsychology 15: 136144, 2001.

MOSTOFSKY SH, LASKER AG, CUTTING LE, DENCKLA MB, ZEE DS: Oculomotor abnormalities in attention deficit hyperactivity disorder: a preliminary study. Neurology 57: 423-430, 2001.

NAGEL BJ, BATHULA D, HERTING M, SCHMITT C, KROENKE CD, FAIR D, NIGG JT: Altered white matter microstructure in children with attention-deficit/hyperactivity disorder. $J$ Am Acad Child Adolesc Psychiatry 50: 283-292, 2011.

NAKAO T, RADUA J, RUBIA K, MATAIX-COLS D: Gray matter volume abnormalities in ADHD: Voxel-based meta-analysis exploring the effects of age and stimulant medication. Am J Psychiatry 168: 1154-1163, 2011.

NEALE BM, MEDLAND SE, RIPKE S, ASHERSON P, FRANKE B, LESCH KP, FARAONE SV, NGUYEN TT, SCHÄFER H, HOLMANS P, DALY M, STEINHAUSEN HC, FREITAG C, REIF A, RENNER TJ, ROMANOS M, ROMANOS J, WALITZA S, WARNKE A, MEYER J, PALMASON H, BUITELAAR J, VASQUEZ AA, LAMBREGTS-ROMMELSE N, GILL M, ANNEY RJ, LANGELY K, O'DONOVAN M, WILLIAMS N, OWEN M, THAPAR A, KENT L, SERGEANT J, ROEYERS H, MICK E, BIEDERMAN J, DOYLE A, SMALLEY S, LOO S, HAKONARSON H, ELIA J, TODOROV A, MIRANDA A, MULAS F, EBSTEIN RP, ROTHENBERGER A, BANASCHEWSKI T, OADES RD, SONUGA-BARKE E, MCGOUGH J, NISENBAUM L, MIDDLETON F, HU X, NELSON S, PSYCHIATRIC GWAS CONSORTIUM: ADHD SUBGROUP: Meta-analysis of genome-wide association studies of attention-deficit/hyperactivity disorder. $J$ Am Acad Child Adolesc Psychiatry 49: 884-897, 2010. 
O’DRISCOLL GA, DÉPATIE L, HOLAHAN AL, SAVION-LEMIEUX T, BARR RG, JOLICOEUR C, DOUGLAS VI: Executive functions and methylphenidate response in subtypes of attention-deficit/hyperactivity disorder. Biol Psychiatry 57: 1452-1460, 2005.

OGRIM G, KROPOTOV J, HESTAD K: The quantitative EEG theta/beta ratio in attention deficit/hyperactivity disorder and normal controls: sensitivity, specificity, and behavioral correlates. Psychiatry Res 198: 482-488, 2012.

OLDEHINKEL M, BECKMANN CF, PRUIM RH, VAN OORT ES, FRANKE B, HARTMAN CA, HOEKSTRA PJ, OOSTERLAAN J, HESLENFELD D, BUITELAAR JK, MENNES M: Attention-deficit/hyperactivity disorder symptoms coincide with altered striatal connectivity. Biol Psychiatry Cogn Neurosci Neuroimaging 1: 353-363, 2016.

PLICHTA MM, VASIC N, WOLF RC, LESCH KP, BRUMMER D, JACOB C, FALLGATTER AJ, GRÖN G: Neural hyporesponsiveness and hyperresponsiveness during immediate and delayed reward processing in adult attention-deficit/hyperactivity disorder. Biol Psychiatry 65: 7-14, 2009.

POIL SS, BOLLMANN S, GHISLENI C, O’GORMAN RL, KLAVER P, BALL J, EICH-HÖCHLI D, BRANDEIS D, MICHELS L: Age dependent electroencephalographic changes in attention-deficit/hyperactivity disorder (ADHD). Clin Neurophysiol 125: 1626-1638, 2014.

PORGES SW: Cardiac vagal tone: a physiological index of stress. Neurosci Biobehav Rev 19: 225-233, 1995.

PORGES SW: The polyvagal perspective. Biol Psychol 74: 116-143, 2007.

PRINCE J: Catecholamine dysfunction in attention-deficit/hyperactivity disorder. J Clin Psychopharmacol 28: 39-45, 2008.

PRIHODOVA I, PACLT I, KEMLINK D, NEVSIMALOVA S: Sleep microstructure is not altered in children with attention-deficit/hyperactivity disorder (ADHD). Physiol Res 61: 125-133, 2012.

REIF A, JACOB CP, RUJESCU D, HERTERICH S, LANG S, GUTKNECHT L, BAEHNE CG, STROBEL A, FREITAG CM, GIEGLING I, ROMANOS M, HARTMANN A, RÖSLER M, RENNER TJ, FALLGATTER AJ, RETZ W, EHLIS AC, LESCH KP: Influence of functional variant of neuronal nitric oxide synthase on impulsive behaviors in humans. Arch Gen Psychiatry 66: 41-50, 2009.

ROMMELSE NN, VAN DER STIGCHEL S, SERGEANT JA: A review on eye movement studies in childhood and adolescent psychiatry. Brain Cogn 68: 391-414, 2008.

ROSS RG, HOMMER D, BREIGER D, VARLEY C, RADANT A: Eye movement task related to frontal lobe functioning in children with attention deficit disorder. J Am Acad Child Adolesc Psychiatry 33: 869-874, 1994.

SALATINO-OLIVEIRA A, GENRO JP, POLANCZYK G, ZENI C, SCHMITZ M, KIELING C, ANSLEMI L, MENEZES AM, BARROS FC, POLINA ER, MOTA NR, GREVET EH, BAU CH, ROHDE LA, HUTZ MH: Cadherin-13 gene is associated with hyperactive/impulsive symptoms in attention/deficit hyperactivity disorder. Am J Med Genet B Neuropsychiatr Genet 168: 162-169, 2015.

SAWAGUCHI T, IBA M: Prefrontal Cortical representation of visuospatial working memory in monkeys examined by local inactivation with muscimol. J Neurophysiol 86: 2041-2053, 2001.

SEEGER G, SCHLOSS P, SCHMIDT MH: Functional polymorphism within the promotor of the serotonin transporter gene is associated with severe hyperkinetic disorders. Mol Psychiatry 6: 235-238, 2001.

SHAW P, ECKSTRAND K, SHARP W, BLUMENTHAL J, LERCH JP, GREENSTEIN D, CLASEN L, EVANS A, GIEDD J, RAPOPORT JL: Attention-deficit/hyperactivity disorder is characterized by a delay in cortical maturation. Proc Natl Acad Sci USA 104: 19649-19654, 2007.

SHAW P, LERCH J, GREENSTEIN D, SHARP W, CLASEN L, EVANS A, GIEDD J, CASTELLANOS FX, RAPOPORT J: Longitudinal mapping of cortical thickness and clinical outcome in children and adolescents with attention-deficit/hyperactivity disorder. Arch Gen Psychiatry 63: 540-549, 2006.

SHIBAGAKI M, YAMANAKA T, FURUYA T: Attention state in electrodermal activity during auditory stimulation of children with attention-deficit hyperactivity disorder. Percept Motor Skills 77: 331-338, 1993.

SHULMAN GL, ASTAFIEV SV, FRANKE D, POPE DL, SNYDER AZ, MCAVOY MP, CORBETTA M: Interaction of stimulus-driven reorienting and expectation in ventral and dorsal frontoparietal and basal ganglia-cortical networks. J Neurosci 29: 4392-4407, 2009.

SCHERES A, MILHAM MP, KNUTSON B, CASTELLANOS FX: Ventral striatal hyporesponsiveness during reward anticipation in attention-deficit/hyperactivity disorder. Biol Psychiatry 61: 720-724, 2007. 
SKOGLI EW, TEICHER MH, ANDERSEN PN, HOVIK KT, ØIE M: ADHD in girls and boys - gender differences in co-existing symptoms and executive function measures. BMC Psychiatry 13: 298, 2013.

SONG SK, YOSHINO J, LE TQ, LIN SJ, SUN SW, CROSS AH, ARMSTRONG RC: Demyelination increases radial diffusivity in corpus callosum of mouse brain. NeuroImage 26: 132-140, 2005.

SONUGA-BARKE EJ: Psychological heterogeneity in AD/HD - a dual pathway model of behaviour and cognition. Behav Brain Res 130: 29-36, 2002.

STEINHAUER SR, HAKEREM G: The pupillary response in cognitive psychophysiology and schizophrenia. Ann NY Acad Sci 658: 182-204, 1992.

STEINHAUER SR, SIEGLE GJ, CONDRAY R, PLESS M: Sympathetic and parasympathetic innervation of pupillary dilation during sustained processing. Int J Psychophysiol 52: 77-86, 2004.

STERMAN MB: EEG markers for attention deficit disorder: pharmacological and neurofeedback applications. Child Study Journal 30: 1, 2000.

THAYER JF, LANE RD: A model of neurovisceral integration in emotion regulation and dysregulation. $J$ Affect Disord 61: 201-216, 2000.

THAYER JF, LANE RD: Claude Bernard and the heart-brain connection: Further elaboration of a model of neurovisceral integration. Neurosci Biobehav Rev 33: 81-88, 2009.

THOMPSON HS: The pupil. In: Adler's physiology of the eye. Clinical application (9th ed.). FH ADLER, WM HART, (eds), St. Louis, Mosby-Year Book, Missouri, 1992, pp 412-441.

TOMASI D, VOLKOW ND: Abnormal functional connectivity in children with attention-deficit/hyperactivity disorder. Biol Psychiatry 71: 443-450, 2012.

TONHAJZEROVA I, FARSKY I, MESTANIK M, VISNOVCOVA Z, MESTANIKOVA A, HRTANEK I, ONDREJKA I: Symbolic dynamics of heart rate variability - a promising tool to investigate cardiac sympathovagal control in attention deficit/hyperactivity disorder (ADHD)? Can J Physiol Pharmacol 94: 579-587, 2016.

TONHAJZEROVA I, ONDREJKA I, ADAMIK P, HRUBY R, JAVORKA M, TRUNKVALTEROVA Z, MOKRA D, JAVORKA K: Changes in the cardiac autonomic regulation in children with attention deficit hyperactivity disorder (ADHD). Indian J Med Res 130: 44-50, 2009.

TONHAJZEROVA I, ONDREJKA I, FARSKY I, VISNOVCOVA Z, MESTANIK M, JAVORKA M, JURKO A Jr, CALKOVSKA A: Attention deficit/hyperactivity disorder (ADHD) is associated with altered heart rate asymmetry. Physiol Res 63: 509-519, 2014.

TONHAJZEROVA I, MESTANIK M: New Perspectives in the Model of Stress Response. Physiol Res 66: 173-185, 2017.

TRIPP G, WICKENS JR: Research Review: Dopamine transfer deficit: a neurobiological theory of altered reinforcement mechanisms in ADHD. J Child Psychol Psychiatry 49: 691-704, 2008.

TRIPP G, WICKENS JR: Neurobiology of ADHD. Neuropharmacol 57: 579-589, 2009.

VALERA EM, FARAONE SV, MURRAY KE, SEIDMAN LJ: Meta-analysis of structural imaging findings in attention-deficit/hyperactivity disorder. Biol Psychiatry 61: 1361-1369, 2007.

VAN EWIJK H, HESLENFELD DJ, ZWIERS MP, BUITELAAR JK, OOSTERLAAN J: Diffusion tensor imaging in attention deficit/hyperactivity disorder: A systematic review and meta-analysis. Neurosci Biobehav Rev 36: 1093-1106, 2012.

WILHELM BJ, WILHELM H, MORO S, BARBUR JL: Pupil response components: studies in patients with Parinaud's syndrome. Brain 125: 2296-2307, 2002.

WON H, MAH W, KIM E, KIM JW, HAHM EK, KIM MH, CHO S, KIM J, JANG H, CHO SC, KIM BN, SHIN MS, SEO J, JEONG J, CHOI SY, KIM D, KANG C, KIM E: GIT1 is associated with ADHD in humans and ADHD-like behaviors in mice. Nat Med 17: 566-572, 2011.

WOOD AC, NEALE MC: Twin studies and their implications for molecular genetic studies: endophenotypes integrate quantitative and molecular genetics in ADHD research. $J$ Am Acad Child Adolesc Psychiatry 49: 874-883, 2010.

ZAHN TP, LITTLE BC, WENDER PH: Pupillary and heart rate reactivity in children with minimal brain dysfunction. J Abnorm Child Psychol 6: 135-147, 1978. 